\title{
LONG-RUN INFORMATION DIFFUSION PROCESSES IN THE PERTH HOUSING MARKET: 1988-2000
}

\author{
GREG COSTELLO \\ Curtin University of Technology
}

\begin{abstract}
In the period since the influential studies by Case and Shiller (1989, 1990), it has been established that housing markets are characterised by information diffusion patterns determined by informational inefficiencies. In Australia, little work has been completed on the long-term patterns of these inefficiencies. This paper examines a rich data set of transactions for the Perth housing market in the period 1988-2000. The results confirm some significant long-term patterns for real house price changes and some close relationships between these patterns and changes in real interest rates.
\end{abstract}

Keywords: Housing, information diffusion, repeat sales, interest rates

\section{INTRODUCTION}

Housing is a most important and unique component of the Australian economy. A major proportion of Australian individual wealth is kept in the form of housing stock and a large proportion of personal consumption expenditure is devoted to housing. In recent years, the Australian housing market has experienced rapidly increasing prices in the capital cities. Housing price booms raise a number of concerns. A boom in housing prices represents a major redistribution of wealth. Homeowners see their equity increase, while non-owners are faced with increasing rents and reduced probability of owning. Shiller (1989) provides examples where house price booms in the U.S. have created labour shortages in boom areas and excess volatility in house prices has created problems with regional financial institutions.

In analysing information diffusion processes in housing markets, we are seeking to identify patterns and processes whereby participants in the housing market use information from various sources in their pricing decisions. Given the economic impact associated with rapidly rising or falling house prices, it is surprising that little research has been completed analysing the nature of house price changes. Empirical studies of housing market efficiency are relatively recent in the finance literature and virtually non-existent in Australia. One of the main reasons for this 
has been the lack of suitable transaction data. The vast majority of studies have been completed in North American markets using aggregate housing market data. Most models of house price movements have focused on macroeconomic variables such as interest rates, income and national demographic trends. This is surprising as the evidence suggests that housing markets are best understood as well defined geographic markets. The fact that regional markets experience different rates of price change throughout the country suggests that macroeconomic variables offer only a partial solution.

The causes of house price changes are still not well understood. This study examines house price changes and informational efficiency within the Perth housing market for the period 1988-2000. The study promotes a methodology whereby housing transaction data is disaggregated into a number of regional submarkets so as to increase the explanatory power of the tests and focus upon the influences of price structure in the patterns of information diffusion in housing markets. The results suggest significant informational inefficiency in the Perth housing market. This inefficiency is characterised by long-term patterns of negative serial correlation. This trend is apparent for all price segments, although it is most pronounced in the mid-price segments. The results also confirm a significant influence for changes in housing loan interest rates. Changes in housing loan interest rates appear to impact negatively on house price changes for periods up to two years and then impact positively after four years.

\section{MOTIVATION AND RELATED LITERATURE}

This study examines issues of housing market efficiency. Housing market efficiency is desirable for the same reasons that market efficiency is desirable in other product or securities markets. If prices provide accurate signals for purchase or disposition of real estate assets, then these prices facilitate the correct allocation of scarce financial resources.

As noted in the introduction, empirical studies of price discovery and information diffusion in housing markets are relatively recent in finance literature. In general, these studies can be classified according to the time period of completion. The central studies in the analysis of real estate market efficiency were by Case and Shiller $(1989,1990)$ and the methodology used in these studies has been closely followed in this study.

Prior to the work of Case and Shiller, a small number of early studies had applied methodology adapted from market efficiency studies for securities markets (Gau, 1985; Guntermann and Smith, 1987; Linneman, 1986; Rayburn, Devaney and Evans, 1987). In general, these studies were models of real estate returns, based on data sets of limited quality. The market models used were either the capital asset pricing model (CAPM) or arbitrage pricing theory (APT) adapted for real estate $88 \quad$ Pacific Rim Property Research Journal, Vol 9, No 2 
markets. These studies variously supported the fact that housing markets were weak-form or semi-strong form efficient after the inclusion of transaction costs. All of these studies acknowledge the difficulties associated with accurate measurement of returns in housing markets.

In contrast to these earlier studies, Case and Shiller (1989) used large aggregate (city-wide) transaction data and reported that housing markets were inefficient. While they did model returns, the main emphasis of their research was on price changes for individual housing units. Case and Shiller (1990) extend the analysis to long-run lag structures and relationships between house prices and important macro economy variables. This work provides further evidence to suggest that housing markets are inefficient in the longer term.

Since the period of Case and Shiller's original work, the majority of studies examining information diffusion processes in real estate markets have used large transaction data sets, with the emphasis on analysis of price changes instead of inferred returns. In general, it is acknowledged that housing markets are not as efficient as markets for other types of goods and services. More recently, the focus for tests of market efficiency has shifted towards a process of disaggregating housing markets so that degrees of market efficiency in and between different housing market segments can be tested.

It is widely acknowledged that the aggregation of data presents problems for the analysis of informational efficiency in housing markets. An obvious problem is that with aggregate data, informational efficiency tests are analogous to tests of market efficiency on a composite stock market index. Important features of a housing market in specific price or location segments can be 'diversified away' by the influence of aggregation. In using aggregate data, we also confront the problem of a 'short time series' for analysis of information diffusion patterns in serial correlation tests. This might create a lack of statistical validity for tests of information diffusion. These issues are specifically addressed in this study.

In their comprehensive review of the real estate market efficiency literature, Gatzlaff and Tirtiroglu (1995) argue that real estate market efficiency should not be viewed as an absolute concept, rather more one of degree. Given real estate market imperfections, it is likely that real estate markets are not as efficient as securities markets and that some regional real estate markets are more or less efficient than others. It is also likely that real estate markets capitalise different types of information at different rates and in differing degrees. Some information may be fully capitalised, whereas prices may fail to reflect some other sets of information.

The absence of centralised market systems and the fact that real estate transactions are bilateral negotiations means that there are significant information lags present 
in real estate markets. Shiller (1989) concisely summarises the characteristics of real estate data and some of the implications for empirical research. The 'longterm patterns' literature for market efficiency in securities markets is also relevant to studies of housing markets. Shiller (1984) and Summers (1986) made significant contributions to this area of the literature.

The existence of long-term patterns suggests that there are kinds of inefficiency in markets that can only be detected by taking a long-term view. This view is consistent with the fact that very small pricing errors may accumulate over time and require long-term corrections that would be observed with negative serial correlation coefficients at longer lag periods.

This is most relevant to housing markets, where it has long been recognised that significant institutional factors impact upon the ability of the market to make corrections consistent with efficient markets theory in the short-term. Very large transaction costs (compared to securities markets) and the absence of short selling opportunities prohibit effective short-term trading rules such as those that may be used in securities markets. This results in an accumulation of pricing errors that will be observed with negative serial correlation for long-term lag periods. Case and Shiller (1990) demonstrate the existence of negative serial correlations in long-term lag structures for housing markets. It is important to note that observed long-term negative serial correlation might still be consistent with an efficient market if the observed negative relationship is spurious. For example, Case and Shiller (1989) argue that observed patterns in housing prices may also be consistent with observed patterns of real interest rate movements.

\section{DATA AND METHODOLOGY}

This study uses housing transaction data, for the city of Perth, Western Australia for the period 1988-2000 to develop a method for the analysis of information diffusion processes within the price-location structure of the city-wide housing market. In this study, fifty individual post-code regions within the city are tested. A check of recent census records confirms that in all regions more than $95 \%$ of households were housed in privately owned dwellings and in most regions, this level was higher than $99 \%$.

The housing transaction data for repeat-sales of individual dwellings for the period 1988-2000 were obtained from the Western Australian Valuer General's Office (VGO). The VGO transaction data were screened so that only 'armslength' transactions were included in the sample. Individual properties with major structural alterations between sales and vacant land sales were not included in the study. 
This data enables the analysis of the aggregate Perth housing market together with specific price-location market segments. The price-location disaggregation procedure should be considered as a two-stage method. In the first stage, the data is classified according to Australian post-code spatial criteria so as to impose specific location segments as factor variables. In stage two, the top fifty post-code regions for number of transactions are selected and the mean real house prices from these location segments are used to rank the segments according to price.

Some descriptive statistics for the data are contained in Table 1, which is presented, so that statistics for the individual post-code regions can be viewed by price rank in ascending order according to the average selling price for the postcode district for the sample period. It is evident from the standard deviations (shown in parentheses) of the mean selling price variable that there are wide ranges of selling prices in some post-code districts. This is a consequence of the large sample taken from the aggregate urban housing market. Some districts are characterised by homogenous building styles in densely populated inner city areas, whereas other districts are characterised by more variation in building styles including dwellings on larger land holdings. A general trend that can be observed is that those districts with the lowest relative standard deviations for mean sale price also tend to have lower relative standard deviations for the age of the building.

The variable $R^{*}$ shown in Table 1 is the effective real annual rate of price change for individual repeat-sales. Further detail for the construction of this variable is given in Costello (2000). Mean values for the $R^{*}$ variables are given for each postcode district. The results for all holding periods have very high relative standard deviations for some districts, a consequence of short term trading. Costello (2000) uses this variable to demonstrate significant differentials in price changes between price quartiles within the aggregate housing market.

Another important characteristic of the data is the presence of seasonality both for variations in demand and observed price changes. Costello (2001) demonstrates that demand for housing in Perth is highest during the first quarter of a year and lowest in the third quarter. A similar though less pronounced relationship exists for real house price changes. For this reason, annual differences are used in the empirical tests that follow.

For the aggregate market and each of the fifty post-code regions, quarterly interval real logarithmic price indices were constructed using the weighted repeat-sales (WRS) method (Case and Shiller, 1989). The main variable studied in the following tests denoted $W_{t}$ is the real logarithmic index number at time $t$ for the weighted repeat-sales index deflated by the consumer price index net of housing

Pacific Rim Property Research Journal, Vol 9, No 2 91 
costs; $W(t)=W R S(t)-\ln (C P I(t))$. This variable is used because the change in logarithmic prices represents the yield under continuous compounding.

Let $\Delta W_{i t}$ represent the real annual change in WRS index $i$ at time $t$, then $\Delta W_{i t}=W_{i t}-W_{i t-4}$. This variable can be used to test the hypothesis that homeowner-investors make inferences from lagged price changes in housing markets by regressing price changes on lagged price changes:

$$
\Delta W_{i t}=\beta_{0}+\sum_{k} \beta_{k} \Delta W_{i t-k}+\varepsilon_{i t}
$$

where $\Delta W_{i t-k}$ are lagged index differences, $\varepsilon_{i t}$ is an identically, independently distributed error term with mean zero and $k=1,2, \ldots, K$, the maximum lag length. With this model, serial correlation is modelled explicitly, therefore if significant diffusion of information from past price changes occurs, $\beta_{k}>0$ or $\beta_{k}<0$ and the observed coefficients should be statistically significant.

This is the general serial correlation model that is applied; however two important econometric issues need to be considered. First, when using repeat-sales data, spurious correlation may occur due to an errors-in-variables problem identified by Case \& Shiller (1989). Second, when using annual index differences with quarterly intervals, an overlapping of sample periods occurs, violating the OLS assumption of independent error terms. These issues are specifically addressed below.

Case \& Shiller (1989) demonstrate that the presence of errors-in-variables creates noise in the estimated WRS index and develop a simple expedient for this problem. Their solution was to split the sample of individual house sales into two random samples and then estimate new WRS indexes, denoted indexes A \& B. Serial correlation tests can be completed by regressing index differences from index A on lagged index differences from index B or vice versa. So from equation (1), the estimating model is of the form:

$$
\Delta W_{i t}=\beta_{0}+\sum_{k} \beta_{1} \Delta W_{j, t-k}+\varepsilon_{i t}
$$

where the subscripts $i$ and $j$ denote the random sub-sample $A$ or $B$ used as either dependent or independent variable. This methodology is used for the results reported in this study. In order to overcome the problem of using annual index differences with quarterly overlapping intervals, a method of moments estimator (Hansen \& Hodrick, 1980; Clapp, Dolde and Tirtiroglu, 1995) was used to estimate the variance matrix of estimated coefficients. A concise explanation of the procedure is given below. 
To increase the explanatory power of the serial correlation tests, from equation (2), the observations for the post-code regions are 'stacked'. The stacking procedure used is such that all variables in a regression have $(T-K) N$ rows, $(T-$ $K)$ quarters for each of $N$ regions. The $(T-K)$ observations for region 1 stacked above the $(T-K)$ observations for region 2 and so on; $(T-K)$ arises as the number of quarterly index intervals available, less those lost for lag length $K$. The results in Tables 2-4 give time-series regression results, pooling the post-code regions to increase explanatory power and reduce standard errors, of the estimates. Stacking the data from the post-code regions can reduce standard errors, because it increases the number of observations in the regression and also because it may increase the variance of independent variables by including cross-region variance. Consistent with the method used by Clapp, Dolde and Tirtiroglu (1995), these are 'stacked' ordinary least squares regressions, effectively ordinary least squares regressions for the set of variables for each post-code region, but constraining all coefficients to be the same across all post-code regions for the city-wide housing market. The method of moments estimator used to estimate the variance matrix of estimated coefficients adjusts the standard errors of the coefficients to take account of the overlap created by using annual differences with quarterly data.

The influence of changes in housing loan interest rates on real house price changes is also tested in this study. Case \& Shiller (1989) argue that the forecastability of changes in real house prices comes about largely because of the forecastability of real interest rates and because housing prices do not take account of information about predicted interest rates. The 1988-2000 period used in these tests includes a number of changes in housing interest rate levels. This includes the period of 1989 in which interest rate levels for housing loans reached 17\% per annum and the period of the mid 1990s, where housing loan interest rates were at levels below $7 \%$ per annum.

The results in Tables 2-4 below also include regressions of annual changes in real house prices on lagged annual changes in housing loan interest rates. For these regressions, the variable $I_{t}$ replaces $W_{t}$ in equation (2). The variable $\Delta I_{t}=I_{t}-I_{t-4}$ represents the logarithmic annual change in housing loan interest rates, where $I=L N\left(H L \_\right.$rate $)$and $H L_{-}$rate is the quarterly interval housing loan rate series of the Australian Bureau of Statistics (ABS).

\section{RESULTS}

The results for various serial correlation tests are presented in Tables 2-4. In Table 2, the lag structure of Case and Shiller (1989) is used with some adaptation since it is also applied to specific price segments. This table provides results for regressions of annual real house price changes on lagged annual real house price 
changes (Part A) and lagged changes in housing loan interest rates (Part B). Results are provided for the full sample of fifty post-code regions in a stacked regression procedure (regression 1), together with results for quintile sub-samples determined according to price rank (see Table 1) for the sample period (regressions 2-6). Quintile 1 represents the cheapest post-code regions, so region 1 is the cheapest region and is stacked above region 2 through region 10. Quintile 5 represents the most expensive post-code regions. This segmentation system enables the influence of the price structure of the market to be observed.

Table 1: W.A. Valuer General's Office repeat-sales data: 1988-2000

\begin{tabular}{|c|c|c|c|c|c|}
\hline \begin{tabular}{l|} 
Australian \\
Postcode \\
District \\
\end{tabular} & $\begin{array}{l}\text { Price } \\
\text { Rank }^{1}\end{array}$ & $\begin{array}{l}\text { Mean sale price } \\
\left(\${ }^{\prime} 000\right) \\
(\text { Std } d e v)\end{array}$ & $\begin{array}{l}\text { Mean year } \\
\text { built } \\
\text { (Std dev) }\end{array}$ & $\begin{array}{l}\text { Mean holding } \\
\text { period (years) }\end{array}$ & $\begin{array}{l}\text { Mean } R^{*} \\
\text { all holding } \\
\text { periods }(\%)^{2}\end{array}$ \\
\hline 6167 & 1 & $74.9(60)^{*}$ & $1974(12) *$ & $4.2(2.5)^{*}$ & $3.4(34)^{*}$ \\
\hline 6061 & 2 & $86.6(19)$ & $1973(12)$ & $4.4(2.4)$ & $3.9(17)$ \\
\hline 6112 & 3 & $87.1(39)$ & $1979(14)$ & $4.2(2.3)$ & $3.3(69)$ \\
\hline 6051 & 4 & $88.4(66)$ & $1974(18)$ & $4.1(2.5)$ & $3.2(20)$ \\
\hline 6064 & 5 & $94.2(30)$ & $1983(7)$ & $4.4(2.4)$ & $2.9(17)$ \\
\hline 6110 & 6 & $94.2(31)$ & $1979(11)$ & $4.6(2.4)$ & $0.5(9)$ \\
\hline 6168 & 7 & $94.5(47)$ & $1979(12)$ & $4.3(2.4)$ & $1.6(13)$ \\
\hline 6107 & 8 & $99.1(36)$ & $1971(15)$ & $4.4(2.4)$ & $2.9(14)$ \\
\hline 6147 & 9 & $99.3(26)$ & $1977(8)$ & $4.6(2.3)$ & $6.1(99)$ \\
\hline 6056 & 10 & $99.5(40)$ & $1973(20)$ & $4.5(2.4)$ & $2.1(12)$ \\
\hline 6054 & 11 & $103.3(35)$ & $1966(22)$ & $4.2(2.4)$ & $6.7(74)$ \\
\hline 6111 & 12 & $105.5(46)$ & $1976(9)$ & $4.4(2.4)$ & $1.3(13)$ \\
\hline 6164 & 13 & $107.2(26)$ & $1986(3)$ & $4.6(2.3)$ & $2.6(43)$ \\
\hline 6053 & 14 & $107.3(38)$ & $1962(22)$ & $4.2(2.4)$ & $5.6(17)$ \\
\hline 6060 & 15 & $108.7(44)$ & $1977(14)$ & $4.2(2.4)$ & $3.7(41)$ \\
\hline 6169 & 16 & $110.6(41)$ & $1982(11)$ & $4.0(2.3)$ & $1.6(9)$ \\
\hline 6210 & 17 & $112.9(57)$ & $1982(12)$ & $4.1(2.4)$ & $2.9(49)$ \\
\hline 6108 & 18 & $113.2(31)$ & $1980(9)$ & $4.5(2.3)$ & $0.4(8)$ \\
\hline 6030 & 19 & $116.9(48)$ & $1989(7)$ & $3.4(2.0)$ & 4.7 (19) \\
\hline 6065 & 20 & $119.5(72)$ & $1979(7)$ & $4.4(2.4)$ & $2.0(12)$ \\
\hline 6101 & 21 & $119.6(36)$ & $1960(25)$ & $4.3(2.3)$ & 4.5 (19) \\
\hline 6100 & 22 & $119.7(52)$ & $1970(23)$ & $4.4(2.4)$ & $5.5(62)$ \\
\hline 6062 & 23 & $120.6(39)$ & $1975(10)$ & $4.8(2.5)$ & $2.6(12)$ \\
\hline 6066 & 24 & $120.8(32)$ & $1989(4)$ & $4.3(2.3)$ & $1.8(7)$ \\
\hline 6163 & 25 & $121.7(48)$ & $1975(13)$ & $4.4(2.4)$ & $3.3(31)$ \\
\hline 6024 & 26 & $124.3(26)$ & $1976(4)$ & $4.6(2.4)$ & $2.4(9)$ \\
\hline 6059 & 27 & $134.1(59)$ & $1976(12)$ & $4.4(2.4)$ & $3.9(30)$ \\
\hline 6025 & 28 & $135.6(66)$ & $1980(7)$ & $4.4(2.4)$ & $2.2(6)$ \\
\hline
\end{tabular}




\begin{tabular}{|c|c|c|c|c|c|}
\hline 6027 & 29 & $138.4(50)$ & $1985(5)$ & $4.3(2.4)$ & $3.0(29)$ \\
\hline 6016 & 30 & $140.2(66)$ & $1955(23)$ & $4.3(2.5)$ & $7.1(61)$ \\
\hline 6019 & 31 & $143.4(72)$ & $1976(14)$ & $4.3(2.4)$ & $4.5(10)$ \\
\hline 6014 & 32 & 147.5 (106) & 1967 (18) & $4.3(2.4)$ & $8.1(41)$ \\
\hline 6155 & 33 & $154.2(52)$ & $1982(7)$ & $4.3(2.4)$ & $2.2(8)$ \\
\hline 6148 & 34 & $155.7(101)$ & $1976(9)$ & $4.5(2.3)$ & $2.7(8)$ \\
\hline 6026 & 35 & $159.0(42)$ & $1985(6)$ & $4.2(2.4)$ & $4.0(42)$ \\
\hline 6157 & 36 & $159.3(123)$ & $1974(18)$ & $4.3(2.3)$ & $4.7(11)$ \\
\hline 6076 & 37 & $161.3(60)$ & $1973(13)$ & $4.3(2.4)$ & $3.3(18)$ \\
\hline 6018 & 38 & $162.8(72)$ & $1970(16)$ & $4.2(2.4)$ & $6.9(32)$ \\
\hline 6012 & 39 & 162.9 (187) & $1965(18)$ & $4.2(2.5)$ & $4.2(14)$ \\
\hline 6152 & 40 & $170.3(82)$ & $1976(14)$ & $4.4(2.4)$ & 3.9 (14) \\
\hline 6023 & 41 & $171.9(70)$ & $1979(6)$ & $4.6(2.4)$ & $3.2(8)$ \\
\hline 6050 & 42 & 174.5 (113) & $1959(21)$ & $4.3(2.4)$ & $6.1(21)$ \\
\hline 6149 & 43 & $177.0(44)$ & $1983(6)$ & $4.6(2.4)$ & $1.8(8)$ \\
\hline 6156 & 44 & $192.8(156)$ & $1969(15)$ & $4.1(2.4)$ & $5.5(11)$ \\
\hline 6020 & 45 & $206.4(88)$ & 1978 (11) & $4.2(2.4)$ & $4.9(13)$ \\
\hline 6151 & 46 & $213.6(143)$ & $1965(21)$ & $4.1(2.5)$ & $8.4(35)$ \\
\hline 6008 & 47 & $218.5(98)$ & $1953(27)$ & $4.2(2.5)$ & $7.8(16)$ \\
\hline 6153 & 48 & $263.1(234)$ & $1974(15)$ & $4.0(2.4)$ & $6.1(12)$ \\
\hline 6010 & 49 & $273.9(180)$ & $1969(22)$ & $4.0(2.3)$ & $7.4(18)$ \\
\hline 6009 & 50 & $370.8(261)$ & $1958(20)$ & $4.4(2.5)$ & 6.7 (13) \\
\hline \multicolumn{6}{|c|}{$\begin{array}{l}\text { This table provides descriptive statistics of the fifty post-code districts used in } \\
\text { the study. The transaction data used was obtained from the W.A. Valuer } \\
\text { General's Office. } \\
\text { 1. The price rank for an individual postcode region is calculated using } \\
\text { Tamhane's T2 post hoc multiple comparison procedure. } \\
2 \text {. The variable } R^{*} \text { is the real annual effective rate of price change for } \\
\text { individual repeat-sales. This variable is constructed according to the procedure } \\
\text { developed by Costello (2000). }\end{array}$} \\
\hline
\end{tabular}

From Table 2 (Part A), it is apparent that there is some weak evidence of positive diffusion of information for annual lags. It appears that in general, about one sixth of a previous annual price change persists into the subsequent annual price change. None of these coefficients are reported at a level of statistical significance and, in general, there is a low level of explanatory power for all regressions. This is due to the high levels of cross-region variance, which increases the standard errors estimated for these coefficients. 
Table 2: Regressions of annual real house price changes on annual lagged price changes and interest rates

\begin{tabular}{|c|c|c|c|c|c|c|}
\hline \multicolumn{7}{|c|}{ Part A: Dependent Variable is $W_{t+4}^{a}-W_{t}^{a}$} \\
\hline & Full Sam & $\begin{array}{l}\text { Quintile 1 } \\
\text { Ranks 1-10 }\end{array}$ & $\begin{array}{l}\text { Quintile 2 } \\
\text { Ranks 11-20 }\end{array}$ & $\begin{array}{l}\text { Quintile 3 } \\
\text { Ranks 21-30 }\end{array}$ & \begin{tabular}{|l|} 
Quintile 4 \\
Ranks 31-40
\end{tabular} & $\begin{array}{l}\text { Quintile 5 } \\
\text { Ranks 41-50 }\end{array}$ \\
\hline $\begin{array}{l}\text { Regression } \\
\text { No. }\end{array}$ & $\begin{array}{l}1 \\
(\mathrm{t})\end{array}$ & $\begin{array}{l}2 \\
(\mathrm{t})\end{array}$ & $\begin{array}{l}3 \\
(\mathrm{t})\end{array}$ & $\begin{array}{l}4 \\
(\mathrm{t})\end{array}$ & $\begin{array}{l}5 \\
(\mathrm{t})\end{array}$ & $\begin{array}{l}6 \\
(\mathrm{t})\end{array}$ \\
\hline Constant & $\begin{array}{l}0.01 \\
(0.6)\end{array}$ & $\begin{array}{l}0.00 \\
(0.6)\end{array}$ & $\begin{array}{l}0.00 \\
(0.2)\end{array}$ & $\begin{array}{l}0.01 \\
(0.6)\end{array}$ & $\begin{array}{l}0.02 \\
(0.9)\end{array}$ & $\begin{array}{l}0.02 \\
(1.2)\end{array}$ \\
\hline $\begin{array}{l}W_{t}^{b}-W_{t-4}^{b} \\
\text { Annual lag }\end{array}$ & $\begin{array}{l}0.17 \\
(1.0) \\
\end{array}$ & $\begin{array}{l}0.17 \\
(1.0) \\
\end{array}$ & $\begin{array}{l}0.10 \\
(0.6) \\
\end{array}$ & $\begin{array}{l}0.22 \\
(1.1) \\
\end{array}$ & $\begin{array}{l}0.14 \\
(0.7) \\
\end{array}$ & $\begin{array}{l}0.17 \\
(0.9) \\
\end{array}$ \\
\hline $\begin{array}{l}R^{2} \\
N \text { observations }\end{array}$ & $\begin{array}{l}0.04 \\
2,100\end{array}$ & $\begin{array}{l}0.03 \\
420\end{array}$ & $\begin{array}{l}0.01 \\
420\end{array}$ & $\begin{array}{l}0.06 \\
420\end{array}$ & $\begin{array}{l}0.02 \\
420\end{array}$ & $\begin{array}{l}0.03 \\
420\end{array}$ \\
\hline \multicolumn{7}{|c|}{ Part B: Dependent Variable is $W_{t+4}^{a}-W_{t}^{a}$} \\
\hline & Full Sam & $\begin{array}{l}\text { Quintile 1 } \\
\text { Ranks 1-10 }\end{array}$ & $\begin{array}{l}\text { Quintile 2 } \\
\text { Ranks 11-20 }\end{array}$ & $\begin{array}{l}\text { Quintile 3 } \\
\text { Ranks 21-30 }\end{array}$ & \begin{tabular}{|l|} 
Quintile 4 \\
Ranks 31-40
\end{tabular} & \begin{tabular}{|l|} 
Quintile 5 \\
Ranks 41-50
\end{tabular} \\
\hline $\begin{array}{l}\text { Regression } \\
\text { No. }\end{array}$ & $\begin{array}{l}1 \\
(\mathrm{t}) \\
\end{array}$ & $\begin{array}{l}2 \\
(\mathrm{t}) \\
\end{array}$ & $\begin{array}{l}3 \\
(\mathrm{t}) \\
\end{array}$ & $\begin{array}{l}4 \\
(\mathrm{t}) \\
\end{array}$ & $\begin{array}{l}5 \\
(\mathrm{t}) \\
\end{array}$ & $\begin{array}{l}6 \\
(\mathrm{t}) \\
\end{array}$ \\
\hline Constant & $\begin{array}{l}-0.01 \\
(0.5) \\
\end{array}$ & $\begin{array}{l}-0.02 \\
(1.1) \\
\end{array}$ & $\begin{array}{l}-0.01 \\
(1.0) \\
\end{array}$ & $\begin{array}{l}-0.01 \\
(0.5) \\
\end{array}$ & $\begin{array}{l}0.00 \\
(0.2)\end{array}$ & $\begin{array}{l}0.00 \\
(0.2)\end{array}$ \\
\hline $\begin{array}{l}I_{t}-I_{t-4} \\
\text { Annual lag }\end{array}$ & $\begin{array}{l}-0.23 \\
(2.7)\end{array}$ & $\begin{array}{l}-0.21 \\
(2.4)\end{array}$ & $\begin{array}{l}-0.23 \\
(2.6)\end{array}$ & $\begin{array}{l}-0.23 \\
(2.6)\end{array}$ & $\begin{array}{l}-0.25 \\
(2.8)\end{array}$ & $\begin{array}{l}-0.24 \\
(3.0)\end{array}$ \\
\hline $\begin{array}{l}R^{2} \\
\text { N observations }\end{array}$ & $\begin{array}{l}0.25 \\
2,100\end{array}$ & $\begin{array}{l}0.21 \\
420\end{array}$ & $\begin{array}{l}0.25 \\
420\end{array}$ & $\begin{array}{l}0.27 \\
420\end{array}$ & $\begin{array}{l}0.28 \\
420\end{array}$ & $\begin{array}{l}0.28 \\
420\end{array}$ \\
\hline \multicolumn{7}{|c|}{$\begin{array}{l}\text { This table provides results for regressions of annual real house price changes } \\
\text { on lagged annual real house price changes (Part A) and lagged changes in } \\
\text { housing loan interest rates (Part B). Results are provided for the full sample of } \\
50 \text { post-code regions in a stacked regression procedure together with results } \\
\text { for quintile sub-samples determined according to price rank for the sample } \\
\text { period. The variables } W \text { and I are defined in the text. In order to overcome the } \\
\text { problem of using annual index differences with quarterly overlapping intervals, } \\
\text { a method of moments estimator (Hansen \& Hodrick, 1980; Clapp, Dolde and } \\
\text { Tirtiroglu, 1995) was used to estimate the standard errors of estimated } \\
\text { coefficients. }\end{array}$} \\
\hline
\end{tabular}


This high cross-region variance supports the view that different rates and patterns of information diffusion apply in different spatial regions. These results appear to be quite consistent for all price quintiles. It is important to remember that the price quintiles are determined according to price levels and not spatial proximity. Within any one price quintile, there are post-code regions with a similar price structure for the sample period, but without any specific pattern of spatial proximity. It has been shown in previous studies (Clapp, Dolde and Tirtiroglu, 1995; Dolde and Tirtiroglu, 1997) that spatial proximity is an important positive influence for information diffusion in housing markets. It has been demonstrated in these studies that spatial proximity in housing sub-markets promotes rational learning behavior independent of price structure.

The results in Table 2 (Part A) are similar to the results reported by Case and Shiller (1989) for four major U.S. housing markets, although in general, Case and Shiller report higher levels of positive diffusion, in the vicinity of one quarter to one third of a previous annual price change persists into the subsequent annual price change. Case and Shiller (1989) proposed that this observed positive diffusion of information could be spurious and be caused by the influence of changes in interest rates. This proposition is tested in Table 2 (Part B).

In Table 2 (Part B), the same real house price changes are regressed on lagged interest rate changes. In contrast to the results for lagged price changes, these regressions exhibit significant negative serial correlation. The higher levels of explanatory power and statistical significance confirm that changes in housing loan interest rates have a significant negative influence on changes in real house prices at lag periods of one year. This influence is consistent for all price quintiles and constitutes strong evidence that the observed positive diffusion of information from lagged price changes is not the result of spurious correlation emanating from the influence of interest rate changes.

Table 3 provides results for regressions of annual real house price changes on long-run, non-overlapping, lagged annual real house price changes (Part A) and similar changes in housing loan interest rates (Part B). This methodology is consistent with that used by Case and Shiller (1990). Results are provided for the full sample of fifty post-code regions in stacked regression procedures. Regressions (1-4) are simple regressions with a single lag as the independent variable. Regression (5) is a multiple regression using all lag periods as independent variables. The lag structure used in regression (5) effectively removes the first three years of the time series 1988-2000, causing some inconsistency when comparing coefficients for different regressions. This was the period 198891, a time corresponding with high volatility in both interest rate and house price movements. 
Table 3: Long-run regressions of annual real house price changes on lagged price changes and interest rates

\begin{tabular}{|c|c|c|c|c|c|}
\hline \multicolumn{6}{|c|}{ Dependent Variable is $W_{t+5}^{a}-W_{t+1}^{a}$} \\
\hline Regression No. & $\begin{array}{l}1 \\
(t)\end{array}$ & $\begin{array}{l}2 \\
(t)\end{array}$ & $\begin{array}{l}3 \\
(t)\end{array}$ & $\begin{array}{l}4 \\
(t)\end{array}$ & $\begin{array}{l}5 \\
(t)\end{array}$ \\
\hline Constant & $\begin{array}{l}0.01 \\
(0.9) \\
\end{array}$ & \begin{tabular}{|l|}
0.03 \\
$(2.3)$ \\
\end{tabular} & \begin{tabular}{|l|}
0.03 \\
$(2.5)$ \\
\end{tabular} & $\begin{array}{l}0.03 \\
(1.7) \\
\end{array}$ & $\begin{array}{l}0.03 \\
(3.5) \\
\end{array}$ \\
\hline $\begin{array}{l}W_{t}^{b}-W_{t-4}^{b} \\
\text { One year }\end{array}$ & $\begin{array}{l}0.03 \\
(0.2)\end{array}$ & - & - & - & $\begin{array}{l}-0.16 \\
(1.4)\end{array}$ \\
\hline $\begin{array}{l}W_{t-4}^{b}-W_{t-8}^{b} \\
\text { Two years }\end{array}$ & - & $\begin{array}{c}-0.20 \\
(1.6)\end{array}$ & - & - & $\begin{array}{l}-0.30 \\
(2.4) \\
\end{array}$ \\
\hline $\begin{array}{l}W_{t-8}^{b}-W_{t-12}^{b} \\
\text { Three years }\end{array}$ & - & - & $\begin{array}{l}-0.25 \\
(2.1) \\
\end{array}$ & - & $\begin{array}{l}-0.30 \\
(2.9)\end{array}$ \\
\hline $\begin{array}{l}W_{t-12}^{b}-W_{t-16}^{b} \\
\text { Four years }\end{array}$ & & & & $\begin{array}{l}0.03 \\
(0.2)\end{array}$ & $\begin{array}{l}-0.06 \\
(0.7)\end{array}$ \\
\hline $\begin{array}{l}R^{2} \\
N \text { observations }\end{array}$ & $\begin{array}{l}0.00 \\
2,050 \\
\end{array}$ & \begin{tabular}{|l|}
0.08 \\
1,850 \\
\end{tabular} & $\begin{array}{l}0.12 \\
1,650 \\
\end{array}$ & $\begin{array}{l}0.00 \\
1,450 \\
\end{array}$ & $\begin{array}{l}0.23 \\
1,450 \\
\end{array}$ \\
\hline \multicolumn{6}{|c|}{ Dependent Variable is $W_{t+5}^{a}-W_{t+1}^{a}$} \\
\hline Regression No. & $\begin{array}{l}1 \\
(t)\end{array}$ & $\begin{array}{l}2 \\
(t)\end{array}$ & \begin{tabular}{|l|}
3 \\
$(t)$
\end{tabular} & $\begin{array}{l}4 \\
(t)\end{array}$ & \begin{tabular}{|l}
5 \\
$(t)$ \\
\end{tabular} \\
\hline Constant & $\begin{array}{l}0.00 \\
(0.3)\end{array}$ & \begin{tabular}{|l|}
0.01 \\
$(1.1)$
\end{tabular} & \begin{tabular}{|l|}
0.03 \\
$(2.3)$ \\
\end{tabular} & \begin{tabular}{|l|}
0.04 \\
$(3.6)$ \\
\end{tabular} & $\begin{array}{l}0.03 \\
(1.4)\end{array}$ \\
\hline $\begin{array}{l}I_{t}-I_{t-4} \\
\text { One year }\end{array}$ & $\begin{array}{c}-0.22 \\
(2.8) \\
\end{array}$ & - & - & - & $\begin{array}{c}-0.06 \\
(0.7) \\
\end{array}$ \\
\hline $\begin{array}{l}I_{t-4}-I_{t-8} \\
\text { Two years }\end{array}$ & - & $\begin{array}{c}-0.14 \\
(2.1) \\
\end{array}$ & - & - & $\begin{array}{l}-0.01 \\
(0.1) \\
\end{array}$ \\
\hline $\begin{array}{l}I_{t-8}-I_{t-12} \\
\text { Three years }\end{array}$ & - & - & $\begin{array}{l}0.06 \\
(0.8) \\
\end{array}$ & - & $\begin{array}{l}-0.01 \\
(0.1) \\
\end{array}$ \\
\hline $\begin{array}{l}I_{t-12}-I_{t-16} \\
\text { Four years }\end{array}$ & & & & $\begin{array}{l}0.22 \\
(3.4) \\
\end{array}$ & $\begin{array}{l}0.19 \\
(2.2) \\
\end{array}$ \\
\hline $\begin{array}{l}R^{2} \\
N \text { observations }\end{array}$ & $\begin{array}{l}0.25 \\
2,050 \\
\end{array}$ & \begin{tabular}{ll|}
0.15 \\
1,850 \\
\end{tabular} & $\begin{array}{l}0.03 \\
1,650 \\
\end{array}$ & $\begin{array}{l}0.33 \\
1,450 \\
\end{array}$ & $\begin{array}{l}0.34 \\
1,450 \\
\end{array}$ \\
\hline \multicolumn{6}{|c|}{ Continued over page... } \\
\hline
\end{tabular}


This table provides results for regressions of annual real house price changes on long-run, non-overlapping, lagged annual real house price changes (Part A) and similar changes in housing loan interest rates (Part B). Results are provided for the full sample of 50 post-code regions in stacked regression procedures. Regressions (1-4) are simple regressions with a single lag as the independent variable. Regression (5) is a multiple regression using all lag periods as independent variables. The lag structure used in regression (5) effectively removes the first three years of the time series 1988-2000 causing some inconsistency when comparing coefficients for different regressions. The variables $W$ and I are defined in the text. In order to overcome the problem of using annual index differences with quarterly overlapping intervals, a method of moments estimator (Hansen \& Hodrick, 1980; Clapp, Dolde and Tirtiroglu, 1995) was used to estimate the standard errors of estimated coefficients.

These results confirm some significant long-run patterns of information diffusion within the housing market. The lag periods tested are non-overlapping intervals of one year through four years. Note that this is a non-overlapping lag structure as used by Case and Shiller (1990). The issue of overlapping quarterly sample periods still exists requiring the method of moments estimation procedure. Regression (1) is for a lag period of one year (5 quarters). The lag structure is different from that used in Table 2 in that there is one extra quarterly interval so that there is no overlap between the dependent and independent variables. The result confirms no significant diffusion of information for this lag period. Regressions (2) and (3) confirm a significant pattern of negative serial correlation for lag periods of two and three years. Regression (4) confirms no significant diffusion of information for a lag period of four years. Regression (5) is a multiple regression including all lag periods.

The lag structure used here removes the first three years of the time series 19882000. In this model, the coefficient for the first yearly lag is significantly negative, confirming a different pattern from that revealed in regression (1). It is likely that the results for regression (1) are heavily influenced by the earlier 1988-2001 period of the index when a housing boom occurred. The results in regression (5) indicate that negative serial correlation for lag periods of one year occurred in the period of the mid and late 1990's. The other coefficients in regression (5) confirm the results of previous models with a significant pattern of negative serial correlation occurring for lag periods of two and three years. It appears that the information of past price changes has little influence on future prices for lag periods of more than three years.

It is apparent in Table 3 (Part B) that similar regressions using lagged interest rate changes have some explanatory power, although the results are quite different from those observed for lagged price changes. Regressions (1) and (2) confirm a 
continuing negative influence for changes in interest rates for lag periods of one and two years. Changes in interest rates appear to have little significant influence for a lag period of three years (regression 3) and a significant positive influence after four years (regression 4). These results are at higher levels of statistical significance than the results for price changes indicating a lower level of crossregion variance. It appears that interest rate changes have quite a consistent influence through all regions. The results in regression (5) indicate a low level of influence for changes in interest rates except for lag periods of four years where there is a significant positive influence. Remembering that this lag structure removes the early period of the index when there was considerable volatility in interest rates, this result is quite consistent with a long period of stable interest rates. The contrasting patterns for lagged changes in prices as compared to lagged changes in interest rates confirm that there is little spurious correlation between the variables.

A question arising from the results in Table 3 concerns potential results for a multiple regression model regressing price changes on lagged price changes and lagged changes in interest rates. This model was tested with the results for the various coefficients quite consistent with those presented in Table 3, therefore the results are not reported.

Finally, to provide further information on the influence of price structure in the market, Table 4 provides results for multiple regressions on individual price quintile sub-samples. These results should be compared to those for the aggregate sample contained in Table 3 regression (5). An interesting feature of these results is the pattern of statistically significant constant terms that appear to increase as the price level of the sample also increases. This confirms the influence of a pricing size effect (Costello, 2001). It is apparent that more expensive properties have higher rates of appreciation than the cheaper properties during this sample period. The results also confirm that higher levels of negative serial correlation are observed for the mid-price levels of the sample. The results for interest rate changes are quite consistent for all sub-samples and with the pattern observed for the aggregate sample.

\section{CONCLUSION}

This study has examined house price changes and informational efficiency within the Perth housing market for the period 1988-2000. A method is used whereby the aggregate Perth housing market is disaggregated into a number of regional submarkets so as to increase the explanatory power of the tests and focus upon the influences of price structure in the patterns of information diffusion in housing markets. The results suggest significant informational inefficiency in the Perth housing market. This inefficiency is characterised by long-term patterns of negative serial correlation. This trend is apparent for all price segments although it

$100 \quad$ Pacific Rim Property Research Journal, Vol 9, No 2


is most pronounced in the mid-price segments. The results also confirm a significant influence for changes in housing loan interest rates. Changes in housing loan interest rates appear to impact negatively on house price changes for periods up to two years and then impact positively after four years. This result could constitute evidence of a four-year cycle in house price movements associated with movements in interest rates. The study has examined a limited time period 1988-2000 and it is likely that these results reflect some specific economic characteristics of this era. The causes of house price changes are still not well understood and there remain many opportunities for continuing research in this area.

Table 4: Long-run regressions on price groups

\begin{tabular}{|c|c|c|c|c|c|}
\hline \multicolumn{6}{|c|}{ Dependent Variable is $W_{t+5}^{a}-W_{t+1}^{a}$} \\
\hline & $\begin{array}{l}\text { Quintile 1 } \\
\text { Ranks 1-10 }\end{array}$ & $\begin{array}{l}\text { Quintile 2 } \\
\text { Ranks 11-20 }\end{array}$ & \begin{tabular}{|l} 
Quintile 3 \\
Ranks 21-30
\end{tabular} & $\begin{array}{l}\text { Quintile } 4 \\
\text { Ranks 31-40 }\end{array}$ & $\begin{array}{l}\text { Quintile 5 } \\
\text { Ranks 41-50 }\end{array}$ \\
\hline $\begin{array}{l}\text { Regression } \\
\text { No. }\end{array}$ & $\begin{array}{l}1 \\
(t)\end{array}$ & $\begin{array}{l}2 \\
(\mathrm{t})\end{array}$ & \begin{tabular}{|l}
3 \\
$(t)$
\end{tabular} & $\begin{array}{l}4 \\
(t)\end{array}$ & \begin{tabular}{|l}
5 \\
$(\mathrm{t})$
\end{tabular} \\
\hline Constant & $\begin{array}{l}0.01 \\
(1.5)\end{array}$ & $\begin{array}{l}0.02 \\
(2.7) \\
\end{array}$ & $\begin{array}{l}0.04 \\
(4.2) \\
\end{array}$ & $\begin{array}{l}0.05 \\
(4.8) \\
\end{array}$ & $\begin{array}{l}0.07 \\
(5.9) \\
\end{array}$ \\
\hline$W_{t}^{b}-W_{t-4}^{b}$ & \begin{tabular}{|l|}
-0.15 \\
$(1.1)$ \\
\end{tabular} & \begin{tabular}{|l|}
-0.22 \\
$(1.9)$ \\
\end{tabular} & \begin{tabular}{|l|}
-0.34 \\
$(2.6)$ \\
\end{tabular} & \begin{tabular}{|l|}
-0.35 \\
$(2.6)$ \\
\end{tabular} & \begin{tabular}{|l|}
-0.31 \\
$(2.7)$ \\
\end{tabular} \\
\hline$W_{t-4}^{b}-W_{t-8}^{b}$ & \begin{tabular}{|l|}
-0.33 \\
$(2.4)$ \\
\end{tabular} & \begin{tabular}{|l|}
-0.37 \\
$(2.8)$ \\
\end{tabular} & \begin{tabular}{|l|}
-0.43 \\
$(3.1)$ \\
\end{tabular} & \begin{tabular}{|l|}
-0.37 \\
$(2.8)$ \\
\end{tabular} & \begin{tabular}{|l|}
-0.39 \\
$(3.1)$ \\
\end{tabular} \\
\hline$W_{t-8}^{b}-W_{t-12}^{b}$ & $\begin{array}{l}-0.30 \\
(2.9) \\
\end{array}$ & \begin{tabular}{|l|}
-0.34 \\
$(3.2)$ \\
\end{tabular} & $\begin{array}{l}-0.39 \\
(3.7) \\
\end{array}$ & $\begin{array}{l}-0.41 \\
(3.9) \\
\end{array}$ & $\begin{array}{l}-0.31 \\
(3.0) \\
\end{array}$ \\
\hline$W_{t-12}^{b}-W_{t-16}^{b}$ & $\begin{array}{l}-0.09 \\
(1.2)\end{array}$ & $\begin{array}{l}-0.12 \\
(1.4)\end{array}$ & $\begin{array}{l}-0.17 \\
(1.8)\end{array}$ & $\begin{array}{l}-0.11 \\
(1.1)\end{array}$ & \begin{tabular}{|l}
-0.16 \\
$(1.8)$
\end{tabular} \\
\hline $\begin{array}{l}R^{2} \\
N \text { observations }\end{array}$ & \begin{tabular}{|l|}
0.23 \\
290 \\
\end{tabular} & $\begin{array}{l}0.29 \\
290 \\
\end{array}$ & \begin{tabular}{|l}
0.41 \\
290 \\
\end{tabular} & \begin{tabular}{|l|}
0.35 \\
290 \\
\end{tabular} & $\begin{array}{l}0.28 \\
290\end{array}$ \\
\hline
\end{tabular}




\begin{tabular}{|c|c|c|c|c|c|}
\hline \multicolumn{6}{|c|}{ Dependent Variable is $W_{t+5}^{a}-W_{t+1}^{a}$} \\
\hline & $\begin{array}{l}\text { Quintile 1 } \\
\text { Ranks 1-10 }\end{array}$ & $\begin{array}{l}\text { Quintile 2 } \\
\text { Ranks 11-20 }\end{array}$ & \begin{tabular}{|l} 
Quintile 3 \\
Ranks 21-30
\end{tabular} & \begin{tabular}{|l} 
Quintile 4 \\
Ranks 31-40
\end{tabular} & $\begin{array}{l}\text { Quintile 5 } \\
\text { Ranks 41-50 }\end{array}$ \\
\hline $\begin{array}{l}\text { Regression } \\
\text { No. }\end{array}$ & $\begin{array}{l}1 \\
(\mathrm{t})\end{array}$ & $\begin{array}{l}2 \\
(\mathrm{t})\end{array}$ & $\begin{array}{l}3 \\
(\mathrm{t}) \\
\end{array}$ & $\begin{array}{l}4 \\
(t)\end{array}$ & $\begin{array}{l}5 \\
(\mathrm{t})\end{array}$ \\
\hline Constant & $\begin{array}{l}0.02 \\
(1.0)\end{array}$ & $\begin{array}{l}0.02 \\
(1.0) \\
\end{array}$ & $\begin{array}{l}0.04 \\
(2.0)\end{array}$ & $\begin{array}{l}0.04 \\
(2.2) \\
\end{array}$ & $\begin{array}{l}0.05 \\
(1.8) \\
\end{array}$ \\
\hline$I_{t}-I_{t-4}$ & \begin{tabular}{|c}
-0.05 \\
$(0.7)$ \\
\end{tabular} & \begin{tabular}{|c}
-0.07 \\
$(1.1)$ \\
\end{tabular} & \begin{tabular}{|l}
-0.06 \\
$(0.8)$ \\
\end{tabular} & $\begin{array}{l}-0.07 \\
(1.0) \\
\end{array}$ & \begin{tabular}{|c}
-0.04 \\
$(0.4)$ \\
\end{tabular} \\
\hline$I_{t-4}-I_{t-8}$ & \begin{tabular}{|l}
-0.03 \\
$(0.4)$ \\
\end{tabular} & $\begin{array}{l}-0.01 \\
(0.1) \\
\end{array}$ & $\begin{array}{l}0.02 \\
(0.3) \\
\end{array}$ & $\begin{array}{l}0.00 \\
(0.1)\end{array}$ & \begin{tabular}{|l}
-0.01 \\
$(0.1)$ \\
\end{tabular} \\
\hline$I_{t-8}-I_{t-12}$ & $\begin{array}{c}-0.02 \\
(0.4) \\
\end{array}$ & $\begin{array}{c}-0.04 \\
(0.7) \\
\end{array}$ & $\begin{array}{l}-0.02 \\
(0.3) \\
\end{array}$ & $\begin{array}{l}0.02 \\
(0.3) \\
\end{array}$ & $\begin{array}{l}0.03 \\
(0.4)\end{array}$ \\
\hline$I_{t-12}-I_{t-16}$ & $\begin{array}{l}0.17 \\
(2.4)\end{array}$ & $\begin{array}{l}0.17 \\
(2.4)\end{array}$ & $\begin{array}{l}0.22 \\
(3.1)\end{array}$ & $\begin{array}{l}0.18 \\
(2.6)\end{array}$ & $\begin{array}{l}0.19 \\
(1.8)\end{array}$ \\
\hline $\begin{array}{l}R^{2} \\
\text { N observations }\end{array}$ & $\begin{array}{l}0.32 \\
290 \\
\end{array}$ & $\begin{array}{l}0.32 \\
290 \\
\end{array}$ & \begin{tabular}{|l}
0.32 \\
290 \\
\end{tabular} & $\begin{array}{l}0.32 \\
290 \\
\end{array}$ & $\begin{array}{l}0.32 \\
290 \\
\end{array}$ \\
\hline \multicolumn{6}{|c|}{$\begin{array}{l}\text { This table provides results for regressions of annual real house price changes on } \\
\text { long-run, non-overlapping, lagged annual real house price changes (Part A) and } \\
\text { similar changes in housing loan interest rates (Part B). Results are provided for } \\
\text { individual price rank sub-samples of post-code regions in stacked regression } \\
\text { procedures. All regressions are multiple regression models using all lag periods } \\
\text { as independent variables. The lag structure used effectively removes the first } \\
\text { three years of the time series } 1988-2000 \text { causing some inconsistency when } \\
\text { comparing these coefficients with previous tables. The variables W and I are } \\
\text { defined in the text. In order to overcome the problem of using annual index } \\
\text { differences with quarterly overlapping intervals, a method of moments estimator } \\
\text { (Hansen \& Hodrick, 1980; Clapp, Dolde and Tirtiroglu, 1995) was used to } \\
\text { estimate the standard errors of estimated coefficients. }\end{array}$} \\
\hline
\end{tabular}

\section{REFERENCES}

Case, K. and Shiller, R. (1989). "The Efficiency of the Market for Single-Family Homes", The American Economic Review, 79: 125-137.

Case, K. and Shiller, R. (1990). "Forecasting Prices and Excess Returns in the Housing Market", Journal of the American Real Estate and Urban Economics Association, 18: 253-273. 
Clapp, J., Dolde, W. and Tirtiroglu, D. (1995). "Imperfect Information and Investor Inferences from Housing Price Dynamics", Real Estate Economics, 23 (3): 239-269.

Costello, G. (2000). "Pricing Size Effects in Housing Markets", Journal of Property Research, 17(3): 203-219.

Costello, G. (2001). "Seasonal Influences in Australian Housing Markets", Pacific Rim Property Research Journal, 7(1): 47-60.

Dolde, W. and Tirtiroglu, D. (1997). "Temporal and Spatial Information Diffusion in Real Estate Price Changes and Variances”, Real Estate Economics, 25(4): 539-565.

Gatzlaff, D. and Tirtiroglu, D. (1995). "Real Estate Market Efficiency: Issues and Evidence", Journal of Real Estate Literature, 3(2): 157-189.

Gau, G. (1985). "Public Information and Abnormal Returns in Real Estate Investment", Journal of American Real Estate and Urban Economics Association, 13: $15-31$.

Guntermann, K. and Smith, R. (1987). "Efficiency of the Market for Residential Real Estate", Land Economics, 63: 34-43.

Hansen, L. and Hodrick, J. (1980). "Forward Exchange Rates as Optimal Predictors of Future Spot Rates: An Econometric Analysis", Journal of Political Economy, 88: 829-53.

Linneman, R. (1986). "An Empirical Test of the Efficiency of the Housing Market", Journal of Urban Economics, 20: 140-154.

Rayburn, W., Devaney, M. and Evans, R. (1987). "A Test of Weak-Form Efficiency in Residential Real Estate Returns", Journal of American Real Estate and Urban Economics Association, 15: 220-233.

Shiller, R. (1984). "Stock Prices and Social Dynamics", Brookings Papers on Economic Activity, 457-498.

Shiller, R. (1989). Market Volatility, The MIT Press, Cambridge, MA, 1989.

Shiller, R. (1990). "Market Volatility and Investor Behaviour", American Economic Review: Papers and Proceedings, 80: 58-62.

Summers, L. (1986). "Does the Stock Market Rationally Reflect Fundamental Values?", Journal of Finance, 41: 591-601.

Pacific Rim Property Research Journal, Vol 9, No 2 